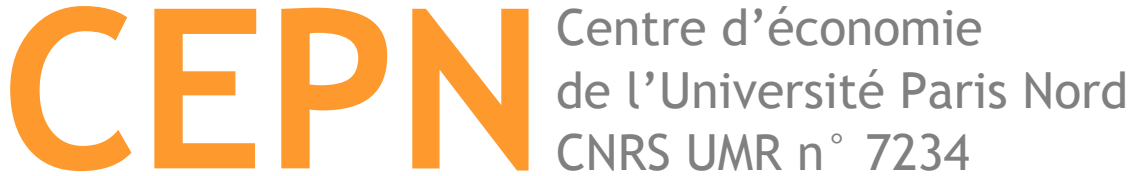

Document de travail $N^{\circ} 2019-03$

Axe : Santé Société et Migrations

\section{A theory of predatory welfare state and citizen welfare: the French case}

\author{
Philippe Batifoulier, Nicolas Da Silva, and Mehrdad Vahabi, \\ CEPN, Université Paris 13, Sorbonne Paris Cité
}

March 2019

\begin{abstract}
In this paper, we argue that the welfare state is an outcome of modern mass (total) warfare. The total war economy requires the participation of all citizens, erasing the difference between the military and citizens. Consequently, the war economy benefits from supporting the civilian population. The total war effect explains why a predatory state undertakes welfare programs. This is one of the contributions of the present paper.

While welfare state is closely related to total warfare, social welfare is not. Fraternal social welfare in the United States preceded the New Deal and the rise of welfare state. Similarly, the French welfare system was born as citizen welfare and not state welfare. In fact, welfare programs were initiated in 1871 during the Paris Commune by workers under the name of la sociale, and it was established as a self-managed citizen welfare in 1945 before being displaced by government welfare programs. A second contribution of this paper is to explore the reappropriating effect or the way self-managed citizen welfare was transformed into a welfare state through a three stage process of reforms in 1946, 1967, and 1996.
\end{abstract}

Keywords: Citizen welfare. La Sociale. Predatory state. State reappropriation effect. Total war effect. Welfare state

JEL Codes: D6, D74, H1, H53, N4, O1 


\section{Introduction}

According to Charles Tilly (1985), war created the state in the Western Europe. In this sense, he advocated a predatory approach to the state ${ }^{2}$. While Tilly's thesis about the predatory nature of the state was crystal clear with regard to warfare state, how can welfare state be analyzed in light of a predatory theory of state? Shouldn't we distinguish two general contradictory types of state, namely a protective (welfare) state and the other predatory state? This is the first question that will be addressed in this paper. We will argue that such a dichotomy is not valid. Our contention is that welfare state is a prolongation of warfare state in the age of total war. In fact, our thesis is a prolongation of Tilly's contention: the welfare state is an outcome of modern mass (total) warfare. The total war economy requires the participation of all citizens, erasing the difference between the military and citizens. Consequently, the war economy benefits from supporting the civilian population. The total war effect explains why a predatory state undertakes welfare programs. This is one of the contribution of the present paper.

Political scientists, sociologists, social historians and reformers have already noted that mass warfare has been a pacemaker of the welfare state. Titmuss (1958) pioneered this idea that was followed by many other scholars (see Obinger and Petersen 2015 for a recent overview). New political economists and economic historians have recently explored and tested the relationship between total warfare, nation-building and the welfare state (Aghion et al. 2012; Alesina and

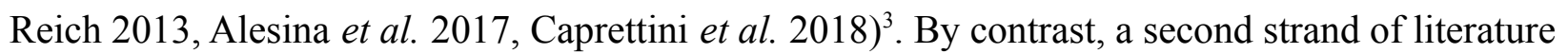
insists on a trade-off between guns and butter, and underlines the negative impact of warfare on welfare spending (see Gal 2007 for a recent survey).

2 By a predatory state, we mean a state that "would specify a set of property rights that maximized the revenue of the group in power, regardless of its impact on the wealth of the society as a whole" (North 1981, p. 22). It would promote private interests of dominant interest groups inside the state (such as politicians, the army, and bureaucrats) or influential private groups with strong lobbying powers (Vahabi 2016). Mainstream economics disregards such type of state, and assumes a contractual state that plays the role of wealth-maximizer for the society. Does a predatory state mean a budget-maximizing state or a bellicose one? Following Usher (1992), we consider taxation is a form of predation and budget-maximizing is a characteristic feature of a predatory state. This is not contradictory with a bellicose state, since the war has often provided an excellent pretext for maximizing the state budget through war economy. Not only has the army benefited from war economy and politicians from an uncontested political authority, some private enterprises have secured colossal rents thanks to their privileged partnership with the influential groups in the state. Max Weber has called it 'booty' or 'political capitalism' (Weber 1922/1968, p. 164166, see also Vahabi 2004).

3 In another note, Ly (2007) examines charitable organizations of terrorist organizations to show the symbiotic relationship of welfare and warfare. 
Our general theory builds upon path dependency models of welfare spending (Olson 1982; Holcombe 2005) and the vast literature on the symbiotic relationship between total war and the welfare state within a predatory approach to the state (Vahabi 2016a, b). Welfare spending increases the state capacity to engage in a total war. Since internal political stability is a prerequisite for victory in the war, all types of governments including military ones seek to insure mass compliance for achieving the official war goals. Along with nationalistic or patriotic propaganda, and repression pursuing the warfare targets, welfare spending may secure mass loyalty and increase self-sacrifice (see Holcombe 2019 and Leeson 2012, 2013 on the role of ideology). This is what Vahabi (2016b: 161) has called the state's domestication technique. A recent study of New Deal spending and patriotism during World War II lends credence to this idea by showing that "US counties receiving more relief payments during the 1930s bought more war bonds, sent more volunteers to the armed forces, and were home to more soldiers displaying conspicuous gallantry on the battlefield...These results are in line with an interpretation that emphasizes individuals reciprocating towards the nation state if their national government came to their aid in bad times" (Caprettini et al. 2018: 23).

While welfare state is closely related to total warfare, social welfare is not. Fraternal social welfare in the United States preceded the New Deal and the rise of welfare state. As extensively documented by Beito (2000), three fraternal types dominated by the late nineteenth century: secret societies, sick and funeral benefit societies. The aid dispensed through organized charities and governments at this time was not only minimal but marked with a stigma. Mutual funds and fraternal societies were based on reciprocity and the self-help. Fraternal societies were displaced by government welfare programs after the Second World War. "The shift from mutual aid and self-help to the welfare-state has involved more than a simple bookkeeping transfer of service provision from one set of institutions to another... The old relationships of voluntary reciprocity and autonomy have slowly given way to paternalist dependency." (Beito 2000, p. 234). Interestingly, a similar process happened in France.

The French welfare system was born as citizen welfare and not state welfare. In fact, welfare programs were initiated in 1871 during the Paris Commune by workers under the name of la sociale, and it was established as a self-managed citizen welfare in 1945 before being displaced by government welfare programs. A second contribution of this paper is to explore the 
reappropriating effect or the way self-managed citizen welfare was transformed into a welfare state in light of a predatory theory of the state.

In doing so, the paper is organized as follows. Section 2 reviews different approaches to public spending particularly path dependency models within public choice perspective. We then introduce a general theory of predatory welfare state and identify the French case of la sociale preceding government welfare. Section 3 investigates the role of mass warfare in the emergence of a centralized welfare state in France. Finally, section 4 documents the French citizen welfare in 1945 and explains how this self-managed welfare system was reappropriated by the state through a three stage process of reforms in 1946, 1967, and 1996. A short conclusion will follow.

\section{Predatory welfare state: general theory}

The expression 'Welfare state' was first coined to describe Labor Britain after 1945: "From Britain the phrase made its way around the world... Attempts were made to re-write nineteenth and twentieth century history, particularly British history, in terms of the 'origin' and 'development' of a 'welfare state"' (Briggs 1961, p. 221). However, there is a difference between the American and the European usage of the term. In the US, there exists a conventional demarcation line between social security and welfare expenditures including notably public assistance, allowances for single-parent families and Medicaid or health assistance. By contrast, in the European case, it pertains to an all-embracing concept capturing not only expenditures on health, pensions, and single-parents families but also those devoted to retraining programs in the labor market and improving housing conditions (Wilensky 1975). Comparing the American and European welfare states, the difference in the usage is often blurred by adopting a middle course theoretical benchmark. For example, borrowing upon Andreassen (1992, p. 336), Overbye's (1995,p. 317) definition “encompasses both 'social security' and 'welfare' the way these concepts are used in the US debate, but excludes retraining programs and housing policies."

What are the sources of 'welfare states'? Generally speaking, at least three explanatory approaches may be distinguished in the welfare literature. While mainstream public goods approach to the state explains welfare spending as an outcome of altruistic preferences of the electorate or a benevolent paternalist ${ }^{4}$ state (Diamond and Mirrlees 1971; Mirrlees 1971;

4 Skocopol (1992) argues that compared to the British or European welfare states, in the US, there exists a maternalist rather than a paternalist welfare state. 
Brennan and Lomaskey 1993), the conventional public choice explains it in terms of rent-seeking activity of the beneficiaries themselves or bureaucrats (Niskanen 1971; Tullock 1983). The shortcomings of both approaches have been underlined by advocates of the insurance approach to welfare spending (Mueller 1989; Overbye 1995). This third approach explains welfare spending as a consequence of the demand for insurance among various risk categories in the electorate rather than as an altruistic or rent-seeking activity for redistribution. Safety rather than redistribution has a stronger explanatory power in tackling at least three issues.

The first issue relates to the beneficiaries of welfare expenditures such as the sick, the disabled, single parent families, the unemployed and the elderly. Putting aside old-age pensioners that enjoy a partial lobbying strength, the voting power of other categories is not especially large and they often lack the means to constitute pressure groups. A second puzzle is the difficulty to explain why beneficiaries of welfare spending have been able to gradually increase their relative share of public expenditures since the Second World War ${ }^{5}$. Finally the problem with a distributional perspective is that redistributional policy measures are supposedly inherently unstable (Tullock 1983, p. 82-83; Mueller 1989, p. 448), whereas existing welfare programs are stable to a large extent. These problems are better explained when welfare programs are considered as safety solutions to social risks (Baldwin 1990) ${ }^{6}$. Market failures due to asymmetric information (notably adverse selection), shared uncertainty, interdependent risks and missing financial markets partially explain compulsory (state) welfare schemes. By combining the theory of market failures with the concept of the median voter, the insurance approach provides a new version of public choice explanation for welfare expenditures. "By focusing on the insurance demands of the median voter, it is possible to construct a theory showing that welfare spending may have a majority backing, even though the immediate beneficiaries at any given position in time will be an (often weak and destitute) minority. It should further be emphasized that the

\footnotetext{
5 For the data, see Overbye (1995, p. 314). According to The Economist (July $14^{\text {th }}-20^{\text {th }} 2018$, p. 12): "Spending on 'social protection', such as pensions, unemployment insurance and assistance for the hard up, has risen from an average of about 5\% of GDP in rich countries in 1960 to $20 \%$ today." Elaborating the ascendancy of a predatory state in the United States, Galbraith (2009) also underlines that the state intervention in health care, higher education, housing, and social security account for nearly 40 percent of total consumption of goods and services. Moreover, the direct contribution of nonmilitary public expenditure at the federal, state, and local levels amounts to another 14 percent of GDP: "the United States is not a "free-market" economy with an underdeveloped or withered state sector." (Galbraith 2009, p. 112).

6 Interestingly, Herce et al. (2001, p. 64) causality test between GDP and social protection expenditure in the European Union indicates the significance of "a sense of security" among the citizens.
} 
policy outcomes resulting from the insurance demands of the median voter need not produce Pareto-superior outcomes." (Overbye 1995, p. 322-323).

This approach favors the demand side of the public sector, disregarding the supply side. Before Niskanen (1971), public choice almost exclusively focused on demand side models dominated by the median voter model. As Holcombe (1989) aptly argued, the emphasis on the demand side of the political market implied that the public sector was a reflection of the median voter's preference. Accordingly, the size of a government is decided by democratic choice which can alter throughout history by extending voting rights to women, racial and minority groups (Peltzman 1980; Meltzer and Richard 1981; Lott and Kenny 1999). Although Niskanen's (1971) model was also built on the median voter, his assumption of budget-maximizing government bureaucracy shifted the attention towards the supply side.

\subsection{From demand to supply side of political market}

The literature on revenue-maximizing or budget-maximizing government emphasizes the supply side of political market. Thus, government size is not an outcome of the median voter's collective choice. As a revenue maximizing Leviathan, government spends as much as it can subject to certain constraints. The constraints might be, among others, democratic institutions (Romer and Rosenthal 1978), constitutional constraints (Brennan and Buchanan 1980), deadweight losses associated with taxes (Becker and Mulligan 2003), and political opposition (Holcombe and Mills 1995).

The question of government size should not be conflated with government growth. The latter relates to the evolution of the state size in a dynamic setting (Holcombe 2005). Path dependency models (Olson 1982; Holcombe 2005) capture government growth. These models build upon the ratchet hypothesis to explain government growth from a supply side perspective. Peacock and Wiseman (1961) pioneered the ratchet assumption and Rassler and Thompson (1985), Higgs (1987, 1991), Holcomb (1989, 1993, 1996, 2002, 2005), Eisner (2000), Obinger and Petersen (2015) applied it by developing evolutionary models of government growth. The assumption pertains to government reactions during critical situations such as wars and economic depressions by ratcheting up expenditures. Once the crisis is over, expenditures diminish but their level will remain higher than pre-crisis level. Accordingly, government growth may be explained by a series of ratchets upward in government expenditures in reaction to crisis. Higgs (1987, p. 62) distinguished between Big Government and big government. The former pertains to 
a "wide scope of effective governmental authority over economic decision-making" while the latter "denotes many resources employed in the performance of governmental functions, perhaps only traditional protective functions." The ratchet effect is related to Big Government. This point had been captured by Peacock and Wiseman (1961) when they were exploring the war-induced transition to a command economy or 'displacement effect'. They argued that this effect was a source of irreversibility since it would alter the citizens' perception of tolerable levels of taxation and shift public revenues and expenditures to higher levels during wartime. They also underlined the ratcheting hypothesis implying that war-induced higher tax rates and expenditures would never return to their prewar levels due to habituation effects, institutional rigidities and new warrelated spending obligations. To put it differently, path dependency explains why the state's revenue and expenditure will never return back to the peacetime level.

"The ratchet hypothesis appears at odds with the rational choice models of government growth (or government size), unless a past crisis causes people to believe that continued highest government expenditures can help avert a future crisis...after the ratchet upward following World War I there was a substantial increase in the growth of non-military federal government spending and regulation in the 1920s, and after World War II non-military federal government expenditures rose from $7.8 \%$ of GDP to $10 \%$, following military spending decreases in each case. Clearly, the non-military expenditure increases after these major wars were not a rational choice response to the crisis" (Holcombe 2005, p. 100).

There are several mechanisms that support the ratchet effect. 1) Discontinuous evolution: although incremental change is the norm in economic and institutional evolution (natura non facit saltum), periods of relative stability are punctuated by rapid, substantial, institutional changes that transform basic rules, policy instruments, agents' roles and state-society relationships. Discontinuous evolution or punctuated equilibrium is a response to intense exogenous or endogenous shocks such as wars, and depressions. 2) State increased autonomy: during a crisis the state can assume a far more autonomous role than society-based theories of politics or the median voter's models may predict. Institutional innovations and radical reforms that might be resisted during normal periods can be executed by the state due to an emergency situation. 3) Irreversibility: the changes introduced during a crisis are often irreversible. Path dependency captures the initial historical situation and the institutional rigidity that forms once the change becomes institutionalized. As Higgs (1991) has argued, war results in an expansion of 
the public sector and has thus a ratcheting effect on the growth of government. After the First and Second World War, the fiscal demands of the state and the number of public sector employees never returned back to prewar levels. New taxes such as income and war-profit taxes were introduced during the First World War (for example, France 1915 and Canada 1917). In the US, a country where tax increases are notoriously repelled, a fiscal revolution happened due to the Second World War. The enforcement of the income tax could hardly have been imagined before the war but once implemented citizens did not rebel against a fait accompli. Borrowing Johnson and Koyama's (2017, p. 2) definition of state capacity in terms of ability to enforce its rules and to raise taxes, total wars led to high-capacity welfare states.

Path dependency models are clearly compatible with the insurance approach. Market failures prevail during random shocks such as wars and economic depressions because of shared uncertainty rather than asymmetric information. Shared uncertainty is inseparable from random shocks, i.e. situations in which both sellers and buyers of insurance are unable to estimate the risk they are confronting. This clearly differs from an asymmetric information situation where sellers or buyers of insurance are able to provide subjective risk estimates (Dryzeck and Goodin 1986). Under shared uncertainty, the state can play the role of "insurer of last resort" since in a situation in which risk calculation is impossible, "population is likely to seek recourse to various types of 'decision rules under uncertainty', such as applying the same probability to all outcomes, or to follow a minimax-decision rule...provided that voters are risk-averse...the application of such rules will sway the electorate (including those who would otherwise have perceived themselves as good risks) in the direction of preferring compulsory insurance" (Overbye 1995, p. 327). Managing shared uncertainty warrants an authority capable of defining the decision rules that can be followed by all agents. Unless challenged, the state often provides such a 'legitimate' authority.

\subsection{Total war effect and welfare state}

We propose an original version of path dependency explanation of welfare state in terms of total war effect. Corwin (1970, p. 4) defines a "total war" by its "functional totality": "the politically ordered participation in the war effort of all personal and social force, the scientific, the mechanical, the commercial, the economic, the moral, the literary and artistic, and the 
psychological." In a word, the whole society transforms into a "war machine" (Pick 1993)7. Total warfare is often referred to the two world wars that were "fought among industrialized powers" (Porter 1994, p. 150). However, Obinger and Petersen (2015, p. 204) extended modern mass warfare to the wars over the period from 1860 to 1960 including Franco Prussian war (18701871).

Contrary to wars of religion and those wars that Toynbee (1950) called 'The sport of Kings', one of the major characteristics of large-scale, modern war is that it is not limited to military professionals, it involves everyone and everything. All citizens are forced to participate in it in one way or another. It is a mobilization of the entire economy for the purpose of war. Accordingly a predatory warfare state benefits from supporting welfare programs.

The state organizes the whole economy and allocates the whole labor power according to the needs of war. The increasing scale and growing intensity of the war stimulates a particular concern in the state for the quantity and quality of biological evolution of its population. Titmuss (1958) distinguished four stages in this progression of biological interests.

The first stage was a concern about the quantity of men available for battle or the ratio of men able to participate in military activity in the total population.

The second stage was about quality or 'fitness for service' of military and naval recruits. The psychological dimension of this fitness has become increasingly important for the state.

The third stage in this progression was a growing concern about the health and well-being of not only the standard of fitness of men of military age but also the whole population and, in particular, of children - the next generation of recruits. This stage was reached in Britain at the beginning of the century during the Boer War, and continued through the First World War. For example, in 1917, the first instalment of a free national health service was offered to both

7 In rational conflict theory, war is regarded as part of the bargaining process to achieve peace. Accordingly, the advocates of rational conflict theory interpreted Clausewitz's 'total' or 'absolute' war (2006/1827) as a war that never happens in reality (Sánchez-Pagés 2009). The only type of war that was assumed to be 'rationally conceivable' was Clausewitz's 'battle' (limited confrontation) to remove misconceptions or asymmetric information between the belligerent parties. This interpretation suffers from a major shortcoming, namely revolutionary wars. In such wars against tyranny, the objective is the total destruction of the enemy and not reaching to a compromise. In fact, Clausewitz's total war explicitly pertained to revolutionary wars that were effective against tyranny. He defined 'total war' with respect to its objectives rather than its means. For him, total war implied a war to the last, targeting the complete destruction of the enemy's military might, its political system or even its culture. He did not describe 'total war' in terms of using modern industrial means requiring the mobilization of the entire society. In this paper, we are using total war in this latter sense. 
civilians and soldiers alike, for the treatment and prevention of venereal disease. It finally led to the National Health Service in 1948.

The fourth stage was a growing concern about 'civilian morale' or what Cyril Falls (1941) called 'demostrategy'. According to Titmuss's interpretation, this meant, in military terms, "that the war could not be won unless millions of ordinary people, in Britain and overseas, were convinced that we had something better to offer than had our enemies-not only during but after the war ( ...) It was a call for social justice; for the abolition of privilege, for a more equitable distributions of income and wealth; for drastic changes in the economic and social life of the country" (Titmuss 1958, p. 82).

The war on large-scale erased the distinctions between the civilian and non-civilian and exposed the whole population to the war's requirements and consequences. "The distinctions and privileges, accorded to those in uniform in previous wars, were greatly diminished. Comprehensive systems of medical care and rehabilitations, for example, had to be organized by the state for those who were injured and disabled. They could not be exclusively reserved for soldiers and sailors, as in the past, but had to be extended to include civilians as well-to those injured in the factories as well as the victims of bombing" (Titmuss 1958, p. 82-83). It is noteworthy that the impact of war was not only from non-civilians to civilians, but also from civilians to non-civilians. For instance, educational and artistic facilities in the form of music, drama and the arts available to civilians in war time could not be limited to them and had to be extended to military forces.

The welfare state was an outcome of the predatory state's need to develop cooperation between the civilian and non-civilian for the successful prosecution of war. If this co-operation is thought to be essential, then inequalities must be reduced and the pyramid of social stratification must be flattened. "War socialism" is the policy of a predatory state in a total war in which the war is not conducted solely by the military professionals. Gustav Stolper had already predicted a drastic and long enduring rise of big government in 1915 that was later known as a 'displacement effect' in economic literature: "The most important shifts [caused by war] will affect the relations between the market economy and the state economy. War has extended the scope of state influence to a degree that, arguably, never will return to its previous level. The heavy interference of the state into the right of self-determination of its citizens, the comprehensive regulation of production and consumption, not only for the purpose of war conduct but also for the sake of 
general social purposes, create a precedent whose repercussions can hardly be eliminated in peacetime" (cited in Obinger and Petersen 2015, p. 211-212).

The importance of the ratchet effect in conjunction with critical situation notwithstanding, our argument underlines an original factor in grasping the emergence of welfare state, namely the total war economy. This point has not been sufficiently explored in the ratchet effect literature. As previously argued, welfare policies are profitable for the state since organizing a total war economy needs the mobilization of all citizens erasing the difference between the military and the civilians. The supply side of the political market notably the creation of a higher state capacity for waging a total war and path dependency (related to displacement effect) explains the predatory nature of the welfare state as a revenue-maximizing state.

\subsection{The French citizen welfare: la Sociale}

The Franco-Prussian war started in July 1870 and terminated by Napoleon III's surrender in Sedan in September 2, 1870. The Second French Empire collapsed and the Third Republic ushered in September 4, 1870. Following the Third Republic, a second phase of this war known as the revolutionary war started in September 4, 1870 when Gouvernement de la Défense Nationale was proclaimed and ended in February $1870^{8}$. Following the defeat, the Paris Commune began in an improvised riot that transformed into a revolution on 18 March 1871 when the army failed to remove the guns of Montmartre. On May 29 the Paris Commune was completely crushed.

The Franco-Prussian war was characterized as a "forerunner" of modern mass warfare (Taithe 2001, p. 22-37). But this mass warfare did not lead to a welfare state ${ }^{9}$. It may be argued that the defeat in war was the cause of such a missing relationship ${ }^{10}$ even though this explanation is not

8 Although the war officially ended in February, it continued in the east of France. "The badly devised armistice led to the destruction of the second largest French army. Immediately after the cessation of hostilities, the elections of 8 February were organized on a purely war or peace platform." (Taithe 2001, p. 178). The Third Republic established in September 1870 lasted until 1940 when France's defeat by Nazi Germany in World War II led to the formation of the Vichy government in France.

9 It should be reminded that the expression 'welfare state' does not exist in French. Its French translation is 'Etat providence', a controversial term, referring to the provision of social protection by a central state that acts as divine providence.

10 In fact, Thomas Marshall $(1865$, p. 82) claimed that "the experience of total war is...bound to have an effect on both the principles of social policy and the methods of social administration. But the nature of this effect will depend to a considerable extent on the fortunes of war - on whether a country is invaded or not, on whether it is victorious or defeated, and on the amount of physical destruction and social disorganization it suffers." 
plausible in light of other historical evidence. For example, according to the data provided by Obinger and Petersen (2015, p. 221), "war significantly pushed spending levels up in exactly those countries which had suffered from a high number of casualties and severe destruction on their homeland territory during both World Wars such as Germany, Belgium, Austria, France, Italy." But the French case is not just the absence of relationship between warfare and welfare state in 1870-71; it is rather the emergence of la Sociale and the "politics of care" (Taithe 1999) in the absence of a strong central authority.

The term 'social' is often used in French as an adjective and its usage as a noun is problematic even for native French speakers. However, "it is as a noun that it acquired real political significance in 1870-1, becoming a political cry. What is meant is complicated. It sums up all aspirations to a social state, a democratic and redistributing form of government integrating what called 'the social question'. Under the term 'social question' all sorts of political agendas could be filled, from Napoleon III's 'extinction of pauperism' to hygienic slum clearance or trade unionism. La Sociale also encompassed a complete renegotiation of all social relationships and all hierarchies and especially the establishment of a society of equals before the judiciary and economic laws" (Taithe 2001, p. 53). The partisans of la Sociale called for both requisitions and rationing in September 1870. But most of the interventions taking place in 1870 happened at the local and departmental levels, and the state often tried to control a posteriori a number of initiatives that were not its own. Among these measures was a moratorium on rents or debts, which postponed the full impact of the war on trade or private income. In fact, "La Sociale was at work largely because the state was so frail that it could not prevent it happening." (ibid, p. 57). For example, Lyon and Marseille funded "the war effort by raising new taxes based on income or the value of capital through long-term borrowings." (ibid, p. 57). These initiatives remained local and did not extend to national level before the First World War.

In our opinion, la Sociale was a French invention that can be defined by two qualities: 1) the provision of social protection and insurance against social hazards; 2) the political selforganization of citizens against the state and related to a war situation. La Sociale was a nonpredatory model of social protection based on citizens' resistance during a time of war. It was 'citizen welfare' and not 'state welfare'. This alternative welfare system was founded on the lower echelons of the municipal administration that developed a programme later imitated by the Commune of Paris. 
There was undoubtedly a power-vacuum that the municipal authorities filled using the paternalist welfare network established by previous governments in Paris. "Within French society the war also called for the state to assume a patriarchal and protective role that it had neither the ambitions nor the ability to fulfil. The politics of care, the duty to care, came to the fore when the state proved unable to deliver the victory that justified the war effort, the self-censorship and the collective emotional and physical investment in war. La Sociale and the Commune grew from the war and from the siege because so much of government and legitimacy became attached both to a hypothetical victory and to the duty of caring for the city at war. The failure to deliver the war, the unwillingness to deliver la Sociale, this new social compact between citizen-soldier and state guarantor of social and political rights, prompted the 18 March insurrection." (Taithe 1999, p. 236).

The March 18 revolution in Paris was largely related to the lack of state's capacity to deliver $l a$ Sociale and assume the 'politics of care'. The state's inability to 'domesticate' citizens generated the insurrection. While the responsibility for the war, the defeat, and even the rationing were attributed to the government, the de facto rationing powers, charity visits and policing practices were initiated by the self-serving municipalities. They combined charity and self-government democracy into small-scale replication of the state of emergency. The Communard political project originated from this confusion between local and national jurisdictions. These disputes revolved around what Taithe (1999, p. 99) called 'the politics of care' of Paris.

The French social service prior to World War can be characterized in terms of private charity and localism (Smith 2003). The hospital administration was the essence of localism: "French hospitals, then, were local poles of power and allegiance, important cultural centers for the civic elite, and one of the last vestiges of the ancien régime. They were redolent of the old corporate order which the revolution had sought to destroy" (ibid, p. 8). The vast majority of the nation's public assistance expenses were borne by the communes (there were, and are, 36000 of these elemental and often miniscule political-territorial units). "At the beginning of the twentieth century, local and private initiatives were still paying for 60 percent of national hospital expenses. The central state played only a marginal role, with the nation's ninety departments... covering most of the remaining 40 percent" (ibid, p. 15). In 1870-71, there were two major sources of anti-statism: one was the French localism and the other was the Paris Commune representing 'citizens in arms'. 
The mass militarization at the time did not stem from the army. It was largely an outcome of mass participation in an improvised civilian war effort. Parisian workers were armed to defend the country, side by side with the army. The leaders of this mass militarization rejected the military values of hierarchical obedience related to traditional army discipline. "While calling all men to arms, revolutionary leaders like Flourens denounced the traditional military systems. The traditional categories or spheres of 'civilian' and 'military' are only valid when one excludes the other: they disappear when one sphere embraces the values of the other" (Taithe 2001, p. 24). In fact, there was a dual power in Paris: the frail state's military power on the one hand, and the nascent military power of 'citizens in arms' in Paris. The former was not able to deliver $l a$ Sociale and the latter was still insufficiently strong to implement it at national level. In our view, the key to understand the French puzzle is to grasp the relationship between mass warfare and $l a$ Sociale within the context of this dual power. The reappropriation of la Sociale or the 'politics of care' by the state required a whole process that could only be initiated in the aftermath of Paris Commune's demise and the rise of a new strong state at the eve of the First World War. Interestingly enough, la Sociale reappeared in 1945: it was reborn in the aftermath of the Third Republic (1870- 1940) through national resistance to Fascism by the civil society and particularly by workers' trade unions. The state capitulated after the armistice of 1940. But resistance characterized all those who chose to fight on following the armistice. "Vichy and the resistance can be treated as parallel, yet antagonistic, historical forces" (Kuisel 1981, p. 128). A dual power generated during the German occupation that was characterized by the military and organizational power of resistance both in the army and civilian associations on the one hand, and the Vichy government, on the other hand. A new reflection about la Sociale was reignited in exile in December 1941. The commission for economic and social problems composed of a small pool of exiles in London was created by De Gaulle to prepare an initial report on social policy under the direction of Hervé Alphand. This report was inspired by Keynes, Beveridge and the example of wartime economic and social policy ${ }^{11}$. "British wartime planners impressed the French subcommittee with their approach to social justice. The British had shown the way by introducing a minimum wage and free social services financed by a progressive income tax." (Kuisel 1981, p. 310). One of the major issues during the most intense period of discussion in the summer and fall of 1942 was how the economy should be directed. "There was the choice 11 See Boris (1963) for understanding the influence of the Beveridge plan on the French resistance in exile. 
between a statist and a syndicalist-corporatist method. Should authority lay with the state fonctionnaire or with self-regulating corporatist bodies, which included labor, and an economic and social parliament?" (Kuisel 1981, p. 161).

The Social Security system was created against the state in 1945. The next sections will dwell upon the originality of the French Social Security as a self-managed system by workers and other groups of civil society. It will be shown that the whole history of the welfare state in France might be summarized by a reappropriation of social security by the state by traversing three stages in 1946, 1967, and 1996.

\section{From warfare state to the emergence of welfare state (1871-1932)}

The aim of this section is to analyze how the French state, born by wars, was renewed after 1870-1871 by the progressive emergence of la Sociale (welfare policies) thanks to the Paris Commune. The transition from traditional social policies, marked by the influence of both Ancien Régime institutions and the post-Revolutionary laissez-faire, to welfare state policies was accomplished through the experience of total war. The French predatory welfare state was built as a response to citizen welfare crushed during the "bloody week"12. Mass war against a demonized enemy was a good way to justify high levels of taxation, centralization of decision and the intrusion into private life (notably with regard to health issues). We call total war effect the progressive abolition of the separation between military and civil dimensions of society which makes possible the intervention of state where it was not before. Total war effect is at the origin of predatory welfare. However, the central state power was still challenged by local authorities (notably communes and counties), charities, mutual aid societies and trade unions.

\subsection{Social security institutions before the emergence of French welfare state}

Until the end of the nineteenth century, the French state was mainly a product of war as Charles Tilly once suggested. Different forms of state refrained to intervene significantly in the economy. André and Delorme (1991, p. 52) ${ }^{13}$ demonstrated that the state's share of GDP was relatively low throughout the century. Public expenditure amounted to $10 \%$ of GDP in $1789,11.7 \%$ in 1815 , $11 \%$ in 1872 , and $12.6 \%$ in 1912 . In 1872 , the public expenditure was mainly devoted to maintain the army $(26.4 \%)$, to pay interests on the public debt $(41.5 \%)$, and to afford expenses

12 Bloody week refers to the week during which the Republic crushed the Paris Commune in March 1871.

13 For the data on the evolution of the state's expenditure in France, see also André and Delorme (1983) and Fontvieille (1976). 
linked to national sovereignty obligations (such as courts, police and law enforcement). The state also invested in transport infrastructure (6.7\%). During this period, "public regulatory, promotional, and entrepreneurial functions were minimal" (Kuisel 1981, p. 8).

The traditional French state was opposed to any interference in the markets and social protection. Henri Hatzfeld (1971) called this non-interference the "liberal objection". It was believed that state's obligation to assist people in need would result in institutionalized laziness among the poor, and it would be dangerous to transform a moral duty into a legal debt. This mistrust regarding state intervention on social issues explains the low level of social expenditures. In 1872 , the share of state expenditure with regard to social affairs was $2 \%$, that of education $2.1 \%$, for housing $0.6 \%$ and for veterans zero percent (André and Delorme 1991, p. 53). The roots of this situation might be sought in the institutions of the Ancien Régime in which the church assumed central functions of instruction, public worship and charity for the poor (Guillaume 1994). With the outburst of a laic Revolution, in a context of declining religious feelings, charity was secularized and became public assistance. Local levels of power were in charge of French public assistance due to parishes' organization legacy.

Hospital's administration was a salient illustration of both localism and marginal state concern for the social question. Funded and governed by church (Imbert 1947, 1988), initially hospitals did not have a medical function, and their population varied including the poor, orphans, sick, elderly, mentally and physically disabled people without family, pregnant women, etc. Hospitals were strongly rooted in the local power network through the influence of the parish. Along with the retreat of faith, charity was replaced progressively by beneficence. Local elites then used hospitals not only as reception centers but also as confinement center for vagabonds and beggars in a context of vagrancy's phobia. Localism had the advantage of being in control of population flow. In 1815 , hospital expenditures represented $0.38 \%$ of GDP, $0.45 \%$ in 1833 and less than $0.6 \%$ until 1870 (Domin 2008a, p. 117).

The development of capitalism made Ancien Régime's social institutions obsolete for the growing labor class. Industrialization, technological progress, urbanization and demographic factors had a destructuring effect on traditional means of socialization, such as family, the church and corporations (Kerr et al. 1964; Wilensky and Lebeaux 1965). According to Robert Castel (1995), the challenge faced by societies since the Middle Ages was to resolve integration and disaffiliation crises (see also De Swaan 1988). Vagrants of the Middle Ages were in a similar 
situation as wretched of the nineteenth century. They were considered as 'dangerous classes' for central power since they were not integrated in society. In fact, the contradiction between economic development and traditional social institutions resulted in a violent confrontation around the social question.

If the crushing of the Paris Commune was the founding act of the Third Republic, this political regime could not put an end to the tension between the state and citizen welfare. Indeed, the Republic was less authoritarian than the Second Empire, and it legalized certain forms of selfgovernment that were formerly prohibited: trade unionism (1884), mutual aid (1898), associations (1901). The laissez-faire paradigm remained dominant with regard to social protection, and the first laws had only a derisory impact on this issue. Some laws were voted on the principle of public assistance for the poor regarding healthcare (1893), childhood assistance (1904) and pensions (1905). They granted a lot of leeway to local authorities to define the scope of assistance.

Government's economic policy remained reluctant to interfere in markets. The "liberal objection" against a compulsory public protection kept the state in its traditional role. In 1912, on the eve of the First World War, the state's share in the GDP was $12.6 \%$. This was only 1.6 point more than the state's share in 1872 , and only 2.6 point more than that of 1789 . The real detonator of welfare state emergence was total war. The army's expenses went up from $26.4 \%$ of the budget in 1872 to $37.7 \%$ in 1900 (André and Delorme 1991, p. 52-53). We can note the first signs of the welfare state's emergence through the population policy conducted in preparation of total war.

\subsection{Population policy and total war effect}

Beyond vagrants' and dangerous classes' control, the state's concern for social policy expanded to biological issues on population (Titmuss 1958). Population policy is a typical aspect of predatory welfare state insofar as it pushes the ambivalence between protection and predation to its extremity. It is hard to challenge the reality of protection offered by the state to its citizens: family allowances, assistance for large families, maternity care, particular attention regarding the military personnel's health care, etc. But this protection was a necessary condition of preparing a total war, and in this sense it was a political and economic prerequisite of predation. As predicted by total war effect, population was progressively seen by government as a coherent mass 
(civilians and militaries) available to reach the (total) war goals. The regimentation of the entire population against a common enemy justifies new fields of interventions for the state.

The issue of depopulation became a state matter at the end of the nineteenth century when it appeared that the natural balance of births and deaths was regularly negative (Becchia 1986). This was the case in 1890, 1891, 1892, 1895 and 1900. The threat of diminishing population size in France was explicitly related to the French military weakness compared to Germany in a context of retaliation. According to a statement attributed to the general Von Moltke: "Since 1871 France loses a battle each year" (Cited in Becchia 1986, p. 210). Germany was a role model for the French state with 2 million children born during the period 1900-1910 whereas in France counted only 800000 children. Accordingly, Louis-Lucien Klotz, the head of Treasury and Police department, stated that "the fight against depopulation is a primordial factor for national defense" (Cited in Becchia 1986, p. 212). The state interest for natalist policies was supported and strengthened by an intense lobbying activity bolstered by numerous associations, particularly stemming from religious and military origins (De Lucas Barusse 2009).

The first measures regarding population policy pertained to political autonomy of citizens by liberalizing marriage $(1907)^{14}$ and by criminalizing abortion and contraception propaganda (1920). In parallel, politics built a public system that encouraged people to reproduce. A job guarantee (1909) and replacement salary (1913) were established to support women's pregnancy and maternity. In 1920, a birth bonus was paid for the third child and beyond. In 1932 the law on family allowances concluded this population policy. Accordingly, financing family allocation funds became compulsory for employees and employers. That law included 4.2 million people. In addition to the quantity of the population, the French predatory welfare state strived to control the quality of birth (Cahen 2014). In the name of protecting the children's future, the state progressively established an intrusive pregnancy control. The law required prenatal exams (funded by the state) and established a supervision of the delivery facility (1928). All of these devices showed that the army is now conceived as an extension of the civilian population whose behavior must be governed in a context of mass warfare.

If the emergence of welfare state laid on population policy, it was also marked by an evolution of the army's relationship with regard to healthcare. Here too protection was analytically

14 For example, the Lemire Law (June 21, 1907) reduced the marriage age to 21 without the parent's consent and omitted the marriage legal costs. 
inseparable from predation. Invented during the nineteenth century, military hygienism can be defined as the "prevention and preservation of the great mass of men who participate in national defense" (Rasmussen 2016b, p. 71). The issue of 'selected recruits' is central to understand the ambivalence between protection and predation. Universal conscription (1905) was seen as a problem for military doctors since it was likely to be a source of massive contamination of the army staff. This explains why physicians were granted great authority to exclude recruits through a Review board. From a military hygienist's viewpoint, "troops are thought of as human capital that should be preserved in the name of their economic value, while death and treatment of patients curb this capital. [...] The selection does not stem from a humanitarian vision aimed at protecting young men from the rigors of barracks life, but from a rationalized and business-like approach of the military tool, according to a perspective of maintaining a capital" (Rasmussen 2016b, p. 76, 82). The care provided for the army predicted contemporary public health problems such as the issue of vaccination. Typhoid was the first large epidemic of the First World War that permitted to update publicly funded prevention-intervention (Rasmussen 2008) ${ }^{15}$. Then, the army constituted a laboratory of experiments for the public policy participating in the erasure of the separation between civil and military.

A final element of the population policy of the French welfare state before the Great War was what Titmuss called the 'civilian moral'. In order to gain people's consent to actively participate in mass warfare, the population needed to believe in their nation's cause as the best among all other nations. The French state defined itself as the nation of equality (and Revolution) and spread a sort of cult of (the Third) Republic. One of the well-known aspects of this phenomenon was the development of public education. The Jules Ferry laws on primary schooling and education $(1881,1882,1886)$, prior to other social laws, were emblematic of the process of nation-building. These laws advocated a patriotic defense of the Third Republic, and pleaded against both confessional teaching as well as socialist and anarchist ideas. Teachers became the "black Hussars" of the Republic.

The preparation of war reshaped identities. For example, even French socialists' political and trade union leaders, who were theoretically internationalists, started to support nationalist policies in the name of the Union sacrée (Sacred union) against the external enemy. In the face of threats of war, social divisions were put aside for the benefit of national defense. The sacred 15 See Viet (2016a) for the case of tuberculosis. 
union called for 'patriots' to pay the "blood tax" (Horne 1989). Every individual was summoned to contribute to the national effort through his compulsory participation in the military service. However, this new citizen's obligation also created a debt towards the citizens for the state. War justified a new form of solidarity that could be observed in the relationship between the state and the citizen army's health: "In the contract between the state and the armed nation, the nation is subject to the payment of the blood tax, but conditional on the state's commitment to undertake its health protection." (Rasmussen 2016a, p. 73) Again, the government seeks to dissolve the differences between the soldier and the civilian to justify the extension of its prerogatives.

If the early signs of the emergence of the French predatory state might be traced back to population policies, the share of the state budget devoted to social issues remained low until the Great War. In 1912, total public budget amounted to $12.6 \%$ of GDP. Only the education budget significantly augmented from 1872 to 1900 integrating the effect of Jules Ferry's laws. It increased from $2.7 \%$ to $7.4 \%$ of the total state budget whereas the budget devoted to veterans and other social intervention decreased from 2\% to 0.8\% (André and Delorme 1991, p. 52, 53). Although population policies predicted the French predatory welfare state, the Great War was the cause.

\subsection{Great war and total war effect}

The French predatory welfare state took off with the Great War. As postulated by the ratchet hypothesis, a radical crisis generates a non-transitory surge of state expenditures. Nevertheless, this period showed something more specific. The political and economic omnipresence of the state in society could be explained by the continuity between civil and military worlds due to mass warfare. The total war effect homogenized the society and submitted it to state power. Material and human destructions are so significant that the state seems to be the last resort insurer facing life uncertainty and the impossibility to return to normal economic activity. This is especially the case with war-disabled, widows and orphans. State appeared as the only institution capable of securing national solidarity mechanisms (protector) while it leads population to war with its disastrous consequences (predator).

The First World War is a clear caesura in terms of public expense level and nature. The ratio of public expenditure to GDP rose from $12.6 \%$ in 1912 (8.8\% for the central state, $3.8 \%$ for local administrations ${ }^{16}$ to $32.8 \%$ (27.8\% and 5\% respectively) in 1920. In 1930, while the share of the

16 In the French administrative system, local authorities or administrations include communes and counties. 
defense budget in public expenditure declined to $31.7 \%$ compared to $37.7 \%$ in 1900 , welfare state expenditures reached to $12 \%$ for veterans compared to $0 \%$ in 1900 . Similarly there was an increase of $4.3 \%$ in social interventions compared to $0.8 \%$ in 1900 . These evolutions became possible with the creation of a general income tax during the war phase in 1914 (Piketty 2018) ${ }^{17}$. The level of mandatory levy, which was stable between 1872 and 1912 (8.1\% and 8.7\% of GDP), significantly augmented in 1920 to attain 12.5\% (André and Delorme 1991, p. 52-56).

Mass warfare gives rise to new categories of population and needs that must be addressed, both to guard against revolutionary social outbursts and to ensure new forms of solidarity born in the battlefield (comrades in arms). Although the war is over, the battlefield now extends to the civilian life. In 1919, a law was passed in order to finance the allocation for war invalids, widows and orphans. The law was gradually extended to professional soldiers (1920), to Alsatians and Lorrainers who fought for Germany (1923) and to war invalids before the First World War (1927). This population represented 1,060,000 invalids, 630,000 widows and orphans and 875,000 ascendants (Sauvy 1965, p. 185). In 1933, veteran pensions' reached a peak of $14.9 \%$ of the state expenditure (Delorme and André 1983, p. 410).

Before 1914, widows were excluded from existing assistance systems. War altered the widows' situation and opened up new rights by virtue of sacred union. The war killed about 1.3 million soldiers leaving behind about 680000 widows, often young mothers (Chaineaud 2009). Widows accounted for $9.4 \%$ of the population in 1851 and $12.9 \%$ in 1911 . While the legislative framework for taking in charge of widows dated back to a law in 1831, "[i]t soon became clear that this law, which had been designed for colonial and other forms of limited warfare, was completely inadequate to the mass slaughter of the Great War" (Lanthier 2003, p. 257). The law of March 31, 1919 reformed pensions for widows. The conditions were less generous because of the greater number of widows. But the law modified the status of widows: they became entitledholders. The war was thought to be a social risk which rendered the status of assisted obsolete: "the gifts of yesterday have become a legal right" (Bette 2016, p. 81).

In addition to the case of widows, the war changed the nineteenth century's habits of assistance during childhood (Rivière 2016). Traditionally, the doctrine for admission was underpinned by the tenet of definitive abandonment: no children left to the assistance can be retrieved (in order to dissuade parents to abandon their children). But since the beginning of the Great War, temporary

17 The tax was adopted in 1914 and was levied in 1915. 
admissions were facilitated for girls and sons of mobilized conscripts (i.e. there was 30\% increase in temporary admissions); and the assistance administration requisitioned underused private buildings to manage overpopulation. This evolution due to war conditions altered the perception of families regarding the role of public authority: "abandonment is no longer seen as a faculty offered to parents by the establishment of ad hoc reception structures financed by public authorities, but as a consequence of the inadequacies of the welfare state "(Rivière 2016, p. 47).

The Great War also disrupted the legislative framework of housing policy (Gustiaud 2016). In August 1914, a large scale moratorium on rents was established with strong compensations for homeowners. The consequences of the war then radically changed the nature of housing policies. Previously, public policy focused on the quality of housing, but the post-war emergency was concerned about the quantity of housing. The population's concern also evolved in the same direction: in a situation of scarcity, social housing was no longer about the poor but concerned everyone, particularly veterans and victims of war. The question attained a nationwide scale leading to the Loucheur act (1928), "daughter of the Great War" (Gusitaud 2016, p. 102), that planned the construction of 260,000 homes over 5 years, for both the working class and the middle class.

The Great War was an uncommon and deep crisis which introduced a radical discontinuity in state expenditures. The irreversible nature of this phenomenon was not only linked to the ratchet hypothesis but also to the total war effect on society. Blurring the border between civilian and military, mass warfare generated a need for national solidarity. After the time of "national union" and "blood tax", the state appeared as the only remedy for millions of people. Policies for wardisabled, widows and orphans explain a considerable part of the phenomenon of path dependency discussed in section 2. Just after the war who would be questioning the assistance to orphans? Laissez-faire gave way to the proliferation of economic planning: "Some form of permanent, rational, economic management was needed to supplement market forces and bring production and consumption into balance" (Kuisel 1981, p. 98). In 1938, the share of public expenditure in GDP reached 26.5\%. However, it should be noted that the growth of central state's size and autonomy (20.1\%) was disputed by local authorities (the size of which was 5.5\%) and, by the emergence of occupational welfare (the share of which was $0.9 \%$ ) (André and Delorme 1991, p. 52). The predatory welfare state was contested by the citizen welfare.

\subsection{Tensions between the state and self-government}


The emergence of French predatory welfare was not purely linear and without asperities. At three levels, state intervention was preceded or contested by self-government organization: private pooling of resources, local power of the communes and unions.

Mass warfare generated human and material destructions that were often addressed by private pooling of resources. The state regained its power over these initiatives within a protectorpredator logic that can be named the reappropriation effect ${ }^{18}$. This process can be illustrated with the case of widows' assistance. Before the Great War, private charities were the only actor to rescue widows. However, with the rapid influx of numerous donations during national collections, the control of the state was strengthened with the creation of a distribution committee in June 1915 (Bette 2016). In 1916, the law required an administrative authorization for the creation of a charity institution and required transparency regarding the accounts to justify the use of gifts and state subsidies. Charity organizations that helped widows quickly found a trusteeship through the creation of National offices. The question of social housing also shows the power of self-organization and private pooling of resources. The vote of the Loucheur law in 1928 was a boon for the very powerful associations of veterans. At the time, one in two Frenchman was a veteran, and there were nearly 3.5 million veteran association affiliates. The action of these groups illustrated that veterans were not passive but active: they self-organized to provide for their members all kinds of benefits, including social protection (Gustiaux 2016). These associations were at the origin of the construction of several thousands of homes.

A second source of competition for state power was the initiative of the communes. Between 1872 and 1938, the share of local authorities' expenditure in GDP grew as fast as that of central state expenditure $(2.8 \%$ to $5.5 \%)$. This evolution revealed the key role of the local level in organizing economic decisions in France. Moreover, the importance of local level lends credence to the thesis of Timothy Smith (2003) according to which the slowness of the emergence of welfare state in France was due to the localist opposition. At the turn of the twentieth century, France was still a nation of small property owners which were reluctant to engage in collective forms of solidarity. Local identities and authorities as remnants of the Ancien Régime constituted "a crucial impediment to the building of the welfare state in France" (Smith 2003: 4). Borrowing upon the archives of the city of Lyon, the author showed that there was a struggle for municipal autonomy against the state. When the National Assembly enforced a law to help the poor, 18 See next section for an elaboration of the reappropriation effect through the state-ization of citizen welfare. 
communes reacted by explaining that they were the only institution that detained the reliable local information to judge who deserved assistance.

Throughout the Great War, cities implemented ambitious social policies to limit the adverse consequences of war and maintain morale: cheap housing, tuberculosis clinics, food aid, etc. (Rasmussen 2016a). Jay (1986) counterfactually demonstrated that during the war, against all odds, the life expectancy of civilians grew. Improved physical wellbeing would be linked to the initiative of municipalities (Jay and Robert 2007). In cities like Paris, London and Berlin, local self-government resulted in an appropriate policy-making on industrial mobilization, supply, and public health, meeting the basic needs of the population. The success of the municipal war policy was then the crucible of the state-ization of social protection (Smith 2003). By 'state-ization', we understand the process of reappropriation of self-governed social protection by the state.

The third major element in challenging state control was trade unionism. French trade unionism is characterized by a tradition of criticism of the state and war. Although French trade unions joined the Sacred Union in 1914, before the war and just in the beginning of the war they were opposed to it, particularly because in their eyes, war was an expression of state power (Pauwels 2016). This challenge of the state's stranglehold over the nation can be illustrated by the truce of fighting between the French and Germans during Christmas 1914 (Brown and Seaton 1984). This framework is not anecdotal and explains why trade unions refused state intervention regarding social protection. In fact, they did not trust the state. The welfare state was thus challenged both by liberals and trade unions influenced by socialist ideas.

Consequently, social insurance laws on health and pensions (1928-1930) and family allowances (1932) did not fall under the welfare state since the state did not run this institution. These laws were based on the principle of the obligation to pay contributions as well as freedom of affiliation. Hence, employees could decide which insurance fund they chose to affiliate. This system, however, suffered from three major weaknesses. On the one hand, insurance funds were strongly dispersed eschewing a financial surface allowing them to provide significant benefits. On the other hand, insurance funds were not managed by the contributors themselves. Employers and religious authorities often managed the latter. The same was true for mutual companies that were often managed by influential local people. Finally, the amount of contributions was too low to allow the institution to be effective. In 1938, social insurance expenditure accounted for $0.9 \%$ of GDP. 
The march towards the Second World War reinforced the tension against the state. In a context of collaboration with the enemy (Paxton 1972), the citizen resistance massively legitimized selfgovernment to solve the social question. Social security was the product of resistance to the state.

\section{Citizen welfare and predatory welfare state}

The modern history of welfare state in France shows its originality, since it was born through national resistance by the civil society and particularly by the workers trade unions to the German occupation. The state was capitulated, and the Social Security was recreated against the state in 1945. La Sociale reappeared once again in France. French Social Security was a model of self-government based on social insurance for workers and managed by the "interested parties". In this section we develop this specific and original aspect of the French experience. This citizen welfare, la Sociale, challenged the welfare state. The history of French Social Security since 1947 can then be reviewed as a process of reappropriation of the organization of social protection by the state. This reappropriation effect, periodized by different steps, led to a predatory welfare state. The state behaved as a predator by giving the power to new management bureaucracies as well as some private insurance institutions while providing a certain level of social protection for those who were most affected by its policy.

\section{1 Post war and the French originality}

It is a popular belief in France that French Social Security was born in the aftermath of the Second World War by the order dated 4 October 1945. However, as shown in section 3, all social insurance institutions covering welfare risks already existed prior to the war. With the laws voted in 1928-1930 and 1932, assistance seemed to have been completely abandoned in favor of insurance. If the year 1945 is still widely remembered as the birthday of the French Social Security in the collective representation, it is because of a major innovation: the foundation of a general regime (régime géneral) for workers social insurance managed by the "interested parties" themselves. The ambition of generalizing social protection in this way came from the project adopted by the National Resistance Council (an organization bringing together all political tendencies to prepare the period after the Libération), titled Les jours heureux (The Happy Days, CNR 1944).

Contrarily to other existing institutions, the régime général was based on three highly innovative principles (Friot 2012, Batifoulier et al. 2019): (i) one unique insurance fund to pay for all social benefits. Unlike earlier periods when small funds prevailed, the objective was to gather within a 
single fund all workers (regardless of their occupation) and all welfare contingencies (illness, accident at work, industrial illness, family, old age). The advantage of a single fund was that it could provide greater financial guarantees (especially by making it possible to set risks off of each other). (ii) Unique and "interprofessional" (inter-branch) contribution rate on wages, entailing funding via a flat-rate industry-wide social contribution. The pre-war funds levied contributions on different bases depending on the firm and the employee's status. The advantage of a flat-rate industry-wide contribution was that it dispensed with differences in treatment among firms. (iii) Owners managed the institution. Management of the social security system was in the hands of the "interested parties", a citizen democracy including notably mutual forms and above all employees and their trade unions' representatives. The boards of directors of the primary funds (locally) were composed of three-quarters of union representatives and onequarter of employers' representatives. This institutional arrangement conferred the management of the institution to workers themselves through trade unions and mutual societies.

The workers' movement that carried social security is essential to understand the French experience. The French model in 1945 is unique because of the workers self-government. The French Social Security is not a state-based system. On the contrary, it was built to avoid state power. This hostility finds its roots in the specific war experience and the role of the state in collaborating with the occupation force. If today the role of Pétain and its government in collaboration is widely known, in 1945 the population also knew that $87 \%$ of all parliamentarians, with the exception of communists (who were impeached and hunted), voted full powers to Pétain, and that employers were also compromised with the occupation forces (Lacroiz-Riz 2007, 2009). Conversely, armed and other civilian forms of resistance to German's and Vichy's institutions were mostly undertaken by workers. "In 1940 and in the shabby years of Vichy, the military elite, the business, financial and bureaucratic elite, and much of the ecclesiastical hierarchy had been discredited. Labor emerged as the group with the least responsibility for the nation's catastrophe. More positively, in the occupation labor had given France the greatest part of the Maquis, the most active elements of the Resistance, and the largest number of oppression's victims. In the plans for a new France, many of the reforms long preached by the unions were accepted as desirable and inevitable" (Lorwin 1952, p. 525) ${ }^{19}$.

19 We intentionally cite an old reference from the early fifties to show that in the aftermath of the war everyone was convinced about the fact that the state as well as the business, financial and bureaucratic elite were discredited because of their collaboration. The same point has also been underlined in Wieviorka (2013) more recently. 
In Europe, war meant the breakthrough of democracy. Mass carnage had created a 'democratic imperative' that could not be expressed by the state. In France the resistance movement had paved the way for more workers power in economic affairs and crowded out the state from a part of social administration. French Social Security was a debt of war and the new citizen welfare was a response taking into account workers' requirements. In 1945 workers were autonomous and had unprecedented political power. So they could impose their self-managed social protection.

At the time, the most famous plan aiming at restructuring social security in the post-war era was the British Beveridge Report issued in November 1942 which became a key reference for social policy debates. The French Social Security in 1945 was far from this reference. To gauge the gap, Titmuss's seminal work (1958) regarding the British case is a good indicator. Titmuss classifies social protection in three categories: (i) Social welfare is the public face of the welfare state and the traditional area of social administration and the central government. It refers to services and benefits as direct payments and universal services in order to assist the poor, the sick, the unemployed, the pensioners, etc. (ii) Fiscal welfare operates only through the medium of the fiscal system: taxation acts, income tax, transfer payments, allowances and deductions under direct systems of taxation, etc. (iii) Occupational welfare distinguishes benefits received by an employee as a result of his employment over the national insurance. It includes vouchers, workplace nurseries, travel subsidies, use of company vehicles, entertainment expenses, sports and gym club membership, etc.

Titmuss highlights occupational welfare in order to show that British social protection also entails benefits for the middle classes. In fact, in Britain, social protection was reduced to public and fiscal welfare in the eyes of the population and could only provide assistance for the poorest at the expense of the middle classes. "The aggregate redistributive effects of social service activity since 1948 have wholly or largely represented a transfer of resources from rich to poor" (Titmuss 1958, p. 38). The tendency to see social policies as something for 'them' rather than 'us' (Sinfield 1978, p. 138) led to a decline in social cohesion.

The French experience of 1945 cannot be pigeonholed in Titmuss's three categories. Since the French social security was not state-dependent, the public and fiscal welfare were irrelevant. Occupational welfare was of no great concern and the state played a crucial role in legislation facilitating occupational welfare (Mann 2009). Neither the state nor companies built French 
social protection. The conceptions of redistribution in Britain and France were radically divergent. In Britain, following Titmuss's thinking, social policies represented the collective consciousness, or general will, of society as a whole, within an 'idealist' tradition (Offer 1999). In France, following trade unions, the class conflict was crucial in creating the balance of political forces that determined social legislation. Workers self-government and the notion of wage labor (salariat) were linked to class conflict (Barbier 2013; Friot 2012).

There was not such a thing as a benevolent government or "Robin Hood" planner. The French historical configuration explains why the trade unions became the major institution of social protection. In France the General Labor Confederation, (Confédération Générale du Travail, CGT), the major ${ }^{20}$ trade union organization, while officially independent from political parties, was close to the communist party in practice. A communist minister Ambroise Croizat was commissioned to build the social security system gradually.

During the same period, the former dominant players had partially lost some of their power. Private health insurance (mutuelles- mutual societies), which controlled social insurances before war in the name of workers, had been discredited because of their poor results and their opposition to the regime général in 1946. Furthermore, war generated less stability and predictability to estimate risk level in ways that collective welfare programs could have been more popular than private insurance in the years immediately following war periods (Einar 1995). Mutual benefits societies joined the Social security in exchange for the management of the "co-payment" in health insurance (called "ticket moderateur"), resulting in a double management of refunds prescriptions and acts of care. By this way, the mutuelles maintained a key role in the complementary insurance business that later became particularly important.

In France, as elsewhere, doctors had the capacity to influence social protection. However, in 1945, the medical power was weakened: the "Council of the Order" for the doctors had been created by Vichy. That stained the ethical reputation and commitment of the profession undermining their claim to self-regulation (Jaunait 2005). It was more difficult to develop their professional lobbying against socialized medicine (Domin 2018b). But doctors managed to preserve their bargaining power regarding the fees that they could charge their patients. Hence, Social security had to negotiate systematically with doctors for fixing the fees.

\subsection{The reappropriation of the social security by the state}

20 In April 1946, the CGT claimed five and a half million members (Lorwin 1952, p. 526). 
Contrary to conventional wisdom, the French social security system is not the outcome of consensus but conflict. Citizen welfare was unacceptable for many political, economic and social forces. The opposition was so strong that there was little room left for the founding rules: central government progressively took control. The central state had great power through the development of nationalization and planning processes after the war (North 2016). But, social security was an exception since it was not under the state's direct control ${ }^{21}$. Workers selfgovernment and the "general regime" starkly opposed to the continuous movement of power centralization in France.

The history of the French social security since 1945 is a history of more power for the state, that we call "state-ization" (the French word is "Etatisation"). The progressive state-ization of the French social security can be described both in terms of objectives pursued and the means employed. This history of reappropriating the social security by the state can be periodized in three stages namely in 1946, 1967, and 1996. The reform frequently relied on special legal processes (decrees) ${ }^{22}$ at each stage. They were legislative texts that the government introduced to bypass citizen's power.

The first stage started in 1946 during which the principle of unique insurance fund was victoriously challenged. Several special funds were created or continued beside the régime général by distinguishing occupational statues: farmers, the self-employed, government workers, executives (white collars), etc. While mutual societies seemed to have been disappeared, they obtained in 1947 the possibility to manage some insurance funds with unions (Morice act). The multiplication of funds was associated to the dissolution of the social and financial unity of the general scheme against the principle of the flat-rate industry-wide contribution and unique and interprofessional (inter-branch) contribution rate on wages (Da Silva 2017).

As an extension of these institutional changes, the 1949 debate in the National Assembly dealt with the foundation of the social security institutions and not only with its applications

21 Social security was not an outcome of nationalization. The post-war nationalization program was a response to the collaborationist attitude of many private employers during the war. The state took the control of certain companies whose owners were discredited during the war (Kuisel 1981). This initiative was in line with the establishment of 'économie dirigée' (planned economy) as a prolongation of war economy. The problem of social security was entirely different, since workers and trade unions such as CGT were not discredited during the war. Interestingly, "the CGT withdrew from the planning apparatus in 1947...Similarly, unions lost control of the government boards of the nationalized firms in the 1950s" (Kuisel 1981, p. 259).

22 “Ordonnances" in French. 
(Batifoulier et al. 2019). The workers' power was now under criticism. As Paul Reynaud (Former president of the Conseil de la République Française) argued: "The only real control should be by the Parliament...since only the parliament has the right to require information and clarification over everything... what are the contributions imposed by the state? This is the very definition of the tax, an income benefit required by the public power... It is always a levy exacted by the state pursuant to an Act regardless of whether the payment is made to the fiscal administration or to the social security funds." (JORF 1949, 4554)

Finally, there was relative agreement about the idea that the social security system belonged to the workers. Despite a very advanced line of critical argument, the 1949 debate did not completely call the institution into question.

1967 is the second key moment of the reappropriation of the social security by the state. The Fifth Republic (created in 1958) is based on a strong and centralizing state embodied by General De Gaulle. A rising number of sectors of the economy were under public control. « By the 1950s the principal institutions of public economic management in France were in place. ..."Nationalized enterprises came under direct state control"... National economic planning was a major instrument for orchestrating public policy and private actors" ... "the state also possessed impressive regulatory powers : investment, credit, prices, wages, and foreign trade were all, in some measure, subject to state control" (Kuisel 1981, p. 253).

But social security remained the last major "bastion of resistance" to state control. This originality was opposed to the conversion of the "hauts fonctionnaires" (senior civil servant) in charge of economic affairs to managing growth. The emergence of the finance ministry as a super-ministry and the center of economic management transformed the debate on social security into a debate on better governance and made the political issue a question of good budget management.

This position was advocated through a paternalistic critic of the institution in 1967. The minister (and Professor of Economics) Jean-Marcel Jeanneney claimed that he wished to defend the 1945's spirit, but recommended a better type of governance. Furthermore, the government attacked two major tenets of the régime général: self-government and unique fund for different risks. The minister justified this strategy in the name of transparency: "that is achieved by a strict distinction of contributions according to their attribution. This distinction is reflected in institutional terms by the creation of three clearly separated national funds. [...] Lastly we 
decided that these funds so laden with new responsibilities to be managed by boards of directors of a new type, based on equal representation in just the same way as the administration of a large number of institutions created by collective agreements since 1945." (JORF 1967, p. 4105)

The 1967 decrees separated risks into three insurance funds with specific coverage missions: illness (with industrial illness and accidents), old age and family. This evolution weakened the institutions by diluting power and financial capacities. Moreover, the reform put an end to the self-government of social security system by substituting nominations to elections and by reducing worker's power on boards. Since 1946, workers had only fifty percent of seats in family insurance. In 1967, this was also extended to health and old age insurances. The employees' lost power was gained by employers who conquered fifty percent of the seats. The government decided to give to the employers the same prerogatives as employees, while welfare benefits were not destined to employers but employees. Social security was no longer worker's property. In 1945, to shun the bureaucratization and subordination of the social security to purely budgetary considerations, workers implemented the self-management of its institutions. In 1967, public authorities accused workers and trade unions of having captured the social security by neglecting and abusing budget constraints (Duchesne 2018).

The third step_in reappropriating the social security by the state started in 1996. The so-called "Plan Juppé" ${ }^{23}$ defined a line within the governmental sphere according to which the state would be better at containing the expenditure than the workers (Bonoli and Palier 2007). Budget limitations became a key dimension in transforming the Social Security to reduce its deficits. Accordingly, the Ministry of National Solidarity ${ }^{24}$ was rebaptised as the "Ministry of accounts" despite trade unions criticisms of giving pride of place to a purely financial logic (Palier 2010). The increase of expenditure linked to longevity and medical progress has served as a justification for the state reappropriation.

But this reappropriation effect is not just a problem of budget shrinkage. It was as if the instrument had become the issue, the means replacing the ends and the budget shrinkage per se becoming the welfare policy (Monnereaud 2009). The state's improved role in organizing social security has not reduced the deficit in the context of focusing on the question of the Social

23 Alain Juppé was the French prime minister in 1996.

24 This Ministry was in charge of managing the social security. 
security "hole"25. Despite the failure of the deficit reduction policy, civil servants supported the reappropriation trajectory because it raised state control over social expenditure.

In order to empower the state, laws were enacted to authorize the Parliament to vote every year on the annual budget for the entire social security as well as the targets of the expenditure's growth. This new parliamentary power allowed the state to control the social security. This was the end of the French historical insurance model: henceforth, it is the state that decides which part of its budget should be allocated to the financing of social security. This new logic of intervention strengthened the state power and crowded out trade unions from the Social Security administration. This trajectory was in line with a major reform of public finance that introduced tax revenues paid to the fiscal administration instead of social contributions (compulsory contributions levied on wages) co-administered by workers and employers.

With the creation of the $\mathrm{CSG}^{26}$ in 1991 and its further development in 1996 and 1997, French Social Security departed from a traditional social insurance system towards a tax-based funding system, relying on state fiscal administration in order to obtain financial resources. Social contributions considerably decreased from $79.6 \%$ of receipts from social security in 1980 to $61.2 \%$ in 2015 . Over the same period, taxes increased from $2.1 \%$ to $24.5 \%$.

Over the past four decades, institutional reforms have enhanced the state's capacity to regulate the social security leading to reinforced state control and, at the same time, a loss of selfmanaged social security by citizens.

Decision makers and managers were closer to the state. In the domain of pension schemes or family allowances, trade unions were no longer "veto players". The French employment management was set by a powerful public bureaucracy where the obligation to commitment and resources is pitted against the obligation to achieve result. In healthcare, in order to give a more direct management to state representatives, a new body (UNCAM - the national union of health insurance organisations was created in 2004) institutionalised a centralized public regulatory authority regarding the decisions taken with regard to the medical acts and services paid for by public health insurance.

25 This is an image constantly referred to in the French media pertaining to the social security deficit. 26 In French, CSG stands for contribution sociale géneralisée (Generalized Social Contribution). 
The new organisation tailored by the state was also managed by state agencies and technical bureaucracies such as the Haute Autorité de Santé27 (French National Authority for Health) or Health regional agency, a new supervisory authority created to facilitate the Ministry of Health to control the hospital sector. The hospital administration became the essence of centralization. The hospital reform subordinated the director of each hospital to the health regional agency and the director of these agencies became a "health commissioner", appointed by the Minister of Health in order to strengthen the central government's influence. "Created under the guise of modernizing public health policy, these agencies merged the regional and local offices of the Ministry of Health and the health insurance funds to improve regional coordination in providing care. Instead of respecting the principle of autonomy that guided the founding of these regulatory agencies, these reforms in fact helped the Ministry of Health regain control of the hospital sector" (Nay et al. 2016, p. 2240).

The chain of command was clear and went from the Minister of Health to the director of the hospital whose powers were strengthened but subordinated to the central state. Because of this state-ization, the role and power of medical professionals and the local authorities were lowered in the background. There were no more countervailing powers, especially in financial matters. Doctors were no longer the "bosses" of the hospital and had to comply with the orders of the management. While the hospital was often the largest employer for small towns and played an important role for the domestic economy, local authorities were pushed out of governance.

An important part of the history of French social security can be reviewed by the process of reappropriation of the social security by a predatory state. The citizens who created the 1945 system were expropriated from their property. The purpose of the 1945 system was to introduce self-government based on everyone's participation in the rules that govern them. It was about implementing a non-state expression of the general interest as first incarnated in la Sociale. Citizen welfare challenged the welfare state. The increase in state control is based on an ideology of "the state as owner" assimilating the "public thing" (res publica) to the government and the state authorities.

\section{Conclusion}

27 The equivalent of NICE (National Institute for health and Care Excellence) in the United Kingdom. The HAS dispenses reliable information about the quality-certification and accreditation criteria. It draws up lists of drugs of low actual clinical benefit that are subject to de-reimbursement. 
In this paper, we argued that the welfare state was an outcome of modern mass (total) warfare. Our general theory built upon path dependency models of welfare spending and the vast literature on the symbiotic relationship between total war and the welfare state within a predatory approach to the state. Subsequently, we introduced the French welfare system as an alternative model. Although it was the outcome of total war, it was born as citizen welfare and not state welfare. The roots of this self-managed welfare can be traced back to la Sociale in 1871.

Reviewing the French case, we showed that la Sociale or the establishment of social protection mechanisms based on the self-government of citizens was born from resistance to the Third Republic in a context of total war against Prussia. This was the starting point for the competition between Citizen Welfare and Predatory Welfare. After the extermination of the Parisian resistance, the central state lacked the capacity to assume the 'politics of care' and deliver $l a$ Sociale. It was only with the Great War that the predatory welfare took off. By its violence and its ability to reformulate the forms of solidarity (comrades-in-arms, national unity), the Great War created new categories of population that the state must take care of: invalids, orphans, widows, veterans. The share of public expenditure in GDP then took an unprecedented acceleration that justified the creation of new taxes such as income tax. The development of the welfare state was not to everyone's taste and met resistance in the associative world, in the communes and in the unions. The social insurance institutions created at the time were not under the responsibility of the state but rather managed by friendly societies and companies.

The Second World War was characterized in France by a separation between the state that collaborated with the German occupying forces and a whole section of the civil society (especially the workers) that organized the resistance. This explains the great originality of the French social security system compared to other European experiences, especially that of England. The moral and military collapse of the state gave rise to the reappearance of the same alternatives posed by the episode of the Paris Commune between state and citizenship; between predatory welfare and citizen welfare. The social security of 1946 was established as citizen welfare: it was not the state that ran the institution but the self-interested (workers and employers).

Finally, we demonstrated that the whole history of the French welfare state in the second half of the 20th century consisted of reappropriating the self-managed citizen welfare by the state through a three stage process of reforms in 1946, 1967, and 1996. 


\section{References}

Aghion, Ph., Persson, T., \& Rouzet, D. (2012). Education and military rivalry. National Bureau of Economic Research, Working Paper 18049, Cambridge, MA, May.

Alesina, A., \& Reich, B. (2013). Nation building. National Bureau of Economic Research, Working Paper18839, Cambridge, MA, February.

Alesina, A., \& Reich, B., and Riboni, A. (2017). Nation-building, nationalism and wars. National Bureau of Economic Research, Working Paper 18839, Cambridge, MA, May.

André, C. \& Delorme, R. (1991). Deux siècles de finances publiques: de l'Etat circonscrit à l'Etat inséré. Revue d'économie financière, Hors-série, 51-64.

Andreassen, B.A. (1992). Article 22. In A. Eide et al. (Eds.), The Universal Declaration of Human Rights - A Commentary. Oslo: Oslo University Press.

Baldwin, P. (1990). The politics of social solidarity. Cambridge: Cambridge University.

Barbier, J-C. (2013). The road to social Europe, A contemporary approach to political cultures and diversity in Europe. London and New York : Routledge.

Batifoulier, P. Da Silva, N. \& Duchesne, V. (2019). The dynamics of conventions: the case of the French Social Security System. Historical Social Research, 43, forthcoming

Becker, G. S. \& Mulligan, C.B. (2003). Deadweight costs and the size of government. Journal of Law and Economics, 46(2), 293-340.

Becchia, A. (1986). Les milieux parlementaires et la dépopulation de 1900 à 1914. Communication, 44, 201-246.

Beito, D. (2000). From mutual aid to the welfare state, fraternal societies and social services, 1890-1967. Chapel Hill and London: The University of North Carolina Press.

Bette, P. (2016). Des œuvres de guerre aux offices nationaux: l'évolution de la prise en charge des veuves de guerre (France, 1914-1924). Comité d'histoire de la sécurité sociale, 9(1), 68-87.

Bonoli, G. \& Palier, B. (2007). When Past Reforms Open New Opportunities: Comparing Old-age Insurance Reforms in Bismarckian Welfare Systems. Social policy \& administration, 41(6), 555-573.

Boris G. (1963). Servir la République : Textes et témoignages. Présentation de Pierre Mendès France. Paris : R. Julliard Évreux.

Brennan, G. \& Buchanan, J. M. (1980). The Power to Tax: Analytical Foundations of a Fiscal Constitution. Cambridge University Press: Cambridge.

Brennan, G. \& Lomasky, L. (1993). Democracy and decision: The pure theory of electoral preference. Cambridge: Cambridge University. 
Briggs, A. (1961). The welfare state in historical perspective. European Journal of Sociology, 2(2), 221258.

Brown, M. \& Seaton, S. (1984). Christmas truce: the western front December 1914. Hippocrene Books: New York.

Cahen, F. (2014). Le gouvernement des grosses en France (1920-1970). Comité d'histoire de la sécurité sociale, 1(7), 34-57.

Caprettini, B., Schmidt-Fischbach, F. \& Voth, H.J. (2018). From welfare to warfare: New Deal spending and patriotism during World war II. CEPR Discussion Paper Series, Economic History, DP 12807, 22 March.

Castel, R. (1995). Les métamorphoses de la question sociale : une chronique du salariat. Fayard: Paris.

Chaineaud, C. (2009). L'amélioration de la protection sociale des veuves dans l'entre-deux-guerres ou la veuve bénéficiaire directe des mesures législatives. Revue d'histoire de la protection sociale, 1(2), 66-76.

Clausewitz, C. (2006/1827). On war. Translated by Michael Howard and Peter Paret, New York: Oxford University Press, electronic resource.

CNR. (1944). Les jours heureux, http://museedelaresistanceenligne.org/media6651-Les-jours-heureuxpar-le-CNR

Corwin, E.S. (1970). Total war and the constitution. New York: Alfred A. Knopf.

Cooter, R. (2003). Of War and Epidemics: Unnatural Couplings, Problematic Conceptions. Social History of Medicine, 16(2), 283-302.

Da Silva, N. (2017). Le mythe du "trou de la Sécu" à l'aune des débats parlementaires de 1949. In Brunet C., Darcillon T., and Rieucau G. (Eds). Economie sociale et économie politique. Regards croisés sur l'histoire et sur les enjeux contemporains, Louvain: Presses universitaires de Louvain.

De Luca Barrusse, V. (2009). La revanche des familles nombreuses : les premiers jalons d'une politique familiale (1896-1939). Comité d'histoire de la sécurité sociale, 2(1), 47-63.

De Swaan, A. (1988). In care of the state: Health care, education, and welfare in Europe and the USA in the modern era. Oxford University Press: Oxford.

Delorme, R. \& André, C. (1983). L'Etat et l'Economie. Seuil: Paris.

Diamond, P.A., \& Mirrlees, J.A. (1971). Optimal taxation and public production: I and II.American Economic Review, 81(March), 8-27, (June), 261-278.

Domin, J-P. (2008a). Une histoire économique de l'hôpital (XIXe-XXe siècles). Une analyse rétrospective $d u$ développement hospitalier. Paris: Comité d'histoire de la sécurité sociale.

Domin, J-P. (2018b). Socialization of healthcare demand and development of the French health system (1890-1938). Business History, DOI: 10.1080/00076791.2018.1454433. 
Duchesne, V. (2018). L'agence, le contrat, l'incitation. Les Agences régionales de santé fer-de-lance administratif de la politique de santé. Journal de gestion et d'économie médicale, 36(4),159-180.

Dryzek, J. \& Goodin, R. (1986). Risk-sharing and social justice: the motivational foundations of the postwar welfare state. British Journal of Political Science, 16(1), 1-34.

Eisner, M.A. (2000). From warfare state to welfare state: World War I, compensatory state-building, and the limits of the modern order. Pennsylvania: The Pennsylvania State University.

Falls, C. (1941). The nature of modern warfare. New York: Oxford University Press.

Fontvieille, L. (1976). Évolution et croissance de l'État français de 1815 à 1969. Économies et sociétés série $A F, 13,1655-2144$.

Friot, B. (2012). Puissances du salariat. Paris: La Dispute.

Gal, J. (2007). The Puzzling Warfare-Welfare Nexus, War \& Society, 26, 99-118.

Galbraith J. (2009). The predator state. New York: Free Press.

Guillaume, M. (1994). La sécurité sociale. Son histoire à travers les textes. Tome 1 -1780-1870. Comité d'histoire de la sécurité sociale: Paris.

Gustiaux, R. (2016). L'empreinte de la grande guerre sur le logement social en France (1912-1928). Comité d'histoire de la sécurité sociale, 9(1), 88-109.

Hatzfeld, H. (1971). Du paupérisme à la sécurité sociale (1850-1945). Armand Colin: Paris.

Hardy, A. (2000). Straight Back to Barbarism: Antityphoid Inoculation and the Great War, 1914. Bulletin of the History of Medicine, 74, 265-290.

Herce, J., Sasvilla-Rivero, S. \& De Lucis, J. (2001). Growth and the welfare state in the European Union: A causality analysis. Public Choice, 109(1/2), 55-68.

Higgs, R. (1987). Crisis and Leviathan: Critical Episodes in the Growth of American Government. Oxford University Press: Oxford and New York.

Higgs, R. (1991). Eighteen problematic propositions in the analysis of the growth of government. Review of Austrian Economics, 5(1), 3-40.

Holcombe, R.G. (1989). The median voter model in public choice theory. Public Choice, 61(2), 115-125.

Holcombe, R.G. (1993). Are there ratchets in the growth of federal government spending? Public Finance Quarterly, 21(1), 33-47.

Holcombe, R.G. (1996). The growth of the federal government in the 1920s. Cato Journal, 16(2), 175199.

Holcombe, R.G. (2002). From Liberty to Democracy: The Transformation of American Government. University of Michigan Press: Ann Arbor.

Holcombe, R.G. (2005). Government growth in the twenty-first century. Public Choice, 124(1/2), 95-114. 
Holcombe, R. (2019). Progressive Democracy: the ideology of the modern predatory state, Public Choice, January, https://link.springer.com/article/10.1007/s11127-019-00637-z

Holcombe, R.G., \& Mills, J.A. (1995). Politics and deficit finance. Public Finance Quarterly, 23(4), 448466.

Horne, J. (1989). "L’impôt du sang". Republican Rhetoric and Industrial Warfare in France 1914-1918. Social History, 14(2), 201-223.

Imbert, J. (1947). Les hôpitaux en droit canonique. Vrin: Paris.

Imbert, J. (1988). Les hôpitaux en France. PUF: Paris.

Jaunait, A. (2005). Comment pense l'institution médicale? Une analyse des codes français de déontologie médicale, Paris: Dalloz.

Jay, W. (1986). The Great War and the British People. Harvard University Press: Cambridge.

Jay, W. \& Robert, J-L (2007). Capital Cities at War: Paris, London, Berlin 1914-1919. Cambridge University Press: Cambridge.

JORF. 1949, n74 A.N. Débats parlementaires. 11 juillet.

JORF. 1967, n85 A. N. Compte-rendu intégral des débats. 26 octobre.

Johnson, N. and Koyama, M. (2017). States and economic growth: capacity and constraints. Explorations in Economic History, 64, April, 1-20.

Kerr, C., Harbison, F., Dunlop, J.T., \& Myers, C.A. (1960). Industrialism and industrial man. Harvard University Press: Cambridge.

Kuisel, R. (1981). Capitalism and the state in modern France. Cambridge: Cambridge University Press:

Lacroix-Riz, A. (2009). Le choix de la défaite : les élites françaises dans les années 1930, Paris: Armand Colin.

Lacroix-Riz, A. (2007). Industriels et banquiers français sous l'Occupation: la collaboration économique avec le Reich et Vichy. Paris, Armand Colin.

Lanthier, M. (2003). War widows and the expansion of the French welfare state. In Proceedings western society for French history, University Press of Colorado.

Leclerc, P. (1996). La sécurité sociale. Son histoire à travers les textes. Tome 2 - 1870-1945. Comité d'histoire de la sécurité sociale: Paris.

Leeson, P. (2012). Ordeals, Journal of Law and Economics, 55(3), 691-714.

Leeson, P. (2013). "God Damn": The law and economics of monastic malediction. Journal of Law Economics and Organization, 30(1), 193-216.

Lorwin, V.R. (1952). French Trade Unions since Liberation, 1944-1951. Industrial and Labor Relations Review, 5(4), 524-539. 
Lott, J.R., \& Kenny, L.W. (1999). Did women's suffrage change the size and scope of government? Journal of Political Economy, 107(6/1), 1163-1198.

Ly, P.E. (2007). The Charitable Activities of Terrorist Organizations. Public Choice, 131(1/2), 177-195.

Mann, K. (2009). Remembering and Rethinking the Social Divisions of Welfare: 50 Years On. Journal of

Social Policy, 38(1), 1-18.

Marshall, T. (1965). Class, Citizen and Social Development. New York: Anchor Books.

Meltzer, A. H., \& Richard, S. F. (1981). A rational theory of the size of government. Journal of Political Economy, 89(5), 914-927.

Mirrlees, J. A. (1971). An exploration in the theory of optimum income taxation. Review of Economic Studies, 38(2), 175-208.

Monneraud, L. (2009). The Dominant Economic(s) Prism in Health Reforms: from Economic Constraint to Economic Paradigm. Central European Journal of Public Policy, 3(2), 22-49.

Mueller, D. (1989). Public choice II. Cambridge: Cambridge University.

Nay, O., Béjean, S. Benamouzig, D. Bergeron, H. Castel, P. \& Ventelou B. (2016). Achieving universal health coverage in France: policy reforms and the challenge of inequalities. Lancet, 387, 2236-2249.

Niskanen, W.A. (1971). Bureaucracy and representative government. Chicago: Aldine-Atherton.

North, D. (1981). Structure and change in economic history. New York, London: W.W. Norton and Company.

Obinger, H. \& Petersen, K. (2015). Mass welfare and the welfare state, causal mechanisms and effects. British Journal of Political Science, 47, 203-227.

Offer, J. (1999). 'Idealist thought, social policy and the rediscovery of informal care'. British Journal of Sociology, 50(3), 467-88.

Olson, M. Jr. (1982). The Rise and Decline of Nations. New Haven: Yale University Press.

Overbye, E. (1995). Explaining welfare spending. Public Choice, 83(3/4), 313-335.

Palier, B. (2010). The Dualizations of the French Welfare System, chapter 3. In B. Palier (ed.), A Long

Goodbye to Bismarck, Amsterdam, Amsterdam university press.

Pauwels, J. (2016). 1914-1918: La Grande guerre des classes. Delga: Paris.

Paxton, R. (1972). Vichy France: old guard and new order, 1940-1944. Columbia University Press: New York.

Peacock, A. T., \& Wiseman, J. (1961). The Growth of Government Expenditures in the United Kingdom. Princeton: Princeton University Press.

Peltzman, S. (1980). The growth of government. Journal of Law and Economics, 23(2), 209- 287. 
Pick, D. (1993). War machine: the rationalization of slaughter in the Modern Age. New Haven: Yale University Press.

Piketty, T. (2018). Top Incomes in France in the Twentieth Century: Inequality and Redistribution, 19011998. Harvard: Harvard University Press.

Porter, B.D. (1994). War and the rise of the state: the military foundations of modern politics. New York:

The Free Press.

Rasmussen, A. (2008). A corps défendant : vacciner les troupes contre la typhoïde pendant la grande guerre. Corps, 2(5), 41-48.

Rasmussen, A. (2015). Préserver le capital humain. Une doctrine hygiéniste pour préparer la guerre démocratique? Mil neuf cent. Revue d'histoire intellectuelle, 33, 75-99.

Rasmussen, A. (2016a). Introduction. Protéger la société de la guerre : de l'assistance aux 'droits sur la nation'. Revue d'histoire de la protection sociale, 9(1), 9-24.

Rasmussen, A. (2016b). Expérimenter la santé des grands nombres : les hygiénistes militaires et l'armée française, 1850-1914. Le mouvement social, 257(4), 71-91.

Rassler, K. A., \& Thompson, W. R. (1985). War making and state making: Government expenditures, tax revenues, and global wars. American Political Science Review, 79(2), 491-507.

Rivière, A. (2016). De l'abandon au placement temporaire: la révolution de l'assistance à l'enfance (Paris, 1870-1920). Revue d'histoire de la protection sociale, 1(9), 26-51.

Romer, T., \& Rosenthal, H. (1978). Political resource allocation, controlled agendas, and the status quo. Public Choice, 33(4), 27-43.

Sánchez-Pagés, S. (2009). Conflict as a part of the bargaining process. The Economic Journal, 119, July, $1189-1207$

Sauvy, A. (1965). Histoire économique et sociale de la France entre les deux guerres, Tome 1. Fayard: Paris.

Sinfield, A. (1978). Analyses in the Social Division of Welfare. Journal of Social Policy, 7, 129-156.

Skocpol, T. (1992). Protecting soldiers and mothers. The origins of social policy in the US. Cambridge and London: The Belknap Press and Harvard University

Smith, T. (2003). Creating the welfare state in France, 1880-1940. Montreal \& Kingston, London, Ithaca: McGill-Queen's University Press.

The Economist (2018). Reforming the welfare state, back to basic liberalism. July $14^{\text {th }}-20^{\text {th }}, 12-13$.

Taithe, B. (1999). Defeated flesh, medicine, welfare, and warfare in the making of modern France. Lanham, Boulder, New York: Rowman \& Littlefield Publishers.

Taithe, B. (2001). Citizenship and wars, France in turmoil 1870-1871. London and New York: Routledge. 
Tilly, C. (1985). War making and state making as organized crime. In Evans, P., Rueschemeyer, D., and Skocpol, T. (Eds.), Bringing the state back in. Cambridge: Cambridge University Press, 169-191.

Titmuss, R. M. (1958). Essays on the welfare state. London: George Allen and Unwin LTD.

Tullock, G. (1983). Economics of income redistribution. Boston: Kluwer Nijhoff.

Usher, D. (1992). The welfare economics of markets, voting, and predation. Ann Arbor: University of Michigan Press.

Vahabi, M. (2004). The Political economy of destructive power. Cheltenham: Edward Elgar.

Vahabi, M. (2016a). The political economy of predation: Manhunting and the economics of escape. New York: Cambridge University Press.

Vahabi, M. (2016b). A positive theory of the predatory state. Public Choice, 168(3-4), 153-175.

Viet, V. (2016). La grande guerre et la lutte antituberculeuse en France. Revue d'histoire de la protection sociale, 1(9), 52-67.

Weber, M. (1922/1968). Economy and society: an outline of interpretive sociology. Vol. 1. New York, NY: Benminster Press.

Wilensky, H. (1975). The welfare state and equality. Berkeley: University of California.

Wilensky, H. and Lebeaux, C. (1965). Industrial society and social welfare. New York: Russell Sage Foundation.

Wieviorka, O. (2013). Histoire de la résistance, 1940 -1945. Paris : Perrin. 